\title{
Problems and Countermeasures of Local Colleges and Universities in Serving the Development of Local Economy and Culture A Case Study of Local Universities in Guangdong
}

\author{
Qiuzhun Wang, \\ ${ }^{1}$ Software Engineering Institute of Guangzhou, Guangzhou, Guangdong 510990, China \\ *Corresponding author. Email: 849309341@qq.com
}

\begin{abstract}
It is not only required intrinsically by the function of higher education, but also demanded by local economic and cultural development that local colleges and universities should serve local economic and cultural development. In the process of promoting the development of local economy and culture, there are some problems for the local colleges and universities in Guangdong that need to be solved, such as the insufficient awareness of serving the local people actively, the inability to meet talent demand in fully supporting the development of local economy, the low conversion rate of scientific research achievements, and the lack of in-depth guidance of local culture, etc. To better perform the role in promoting the local economic and cultural development in Guangdong, the local colleges and universities should strengthen their local positioning and improve the social service consciousness, grasp the local talent demand and train high quality applied talents, grasp the local science and technology demand and improve the ability of scientific and technological achievements transformation and grasp the local cultural demand and strengthen the construction of cultural transmission.
\end{abstract}

Keywords: Local colleges and universities, Service, Local economy and culture.

\section{INTRODUCTION}

Local colleges and universities are closely related to the development of local economy. Local colleges and universities can provide high-quality talents and relatively perfect scientific and technological support for local economic and cultural development, which is an important pillar of local economic and cultural development [1]. Against the background of the rapid development of national economy and culture, an important aspect that local colleges and universities should pay attention to in running schools is how to maximize their positive role in the development of local economy and culture. Local colleges and

*Fund: Scientific Research Team Construction Project of Software Engineering Institute of Guangzhou University (ST202004): stage achievements of the research team of the Party's Century-old Culture and Land Policy; stage results of the second batch of university-level "One Teacher, One Excellent Course" Construction Project in Software Engineering Institute of Guangzhou University. universities should be clear about the relationship between themselves and local economic and cultural development, clear about their own characteristics of running schools, and integrate local characteristics to carry out teaching, so as to better serve local economic and cultural development. At present, although local colleges and universities in Guangdong have played a good role in promoting the development of local economy and culture, there are still some problems, which are not conducive to the development of local economy and culture. Therefore, it is of great significance to explore the problems in promoting the development of local economy and culture in Guangdong's local colleges and universities, and to think about the countermeasures corresponding to these problems. This not only helps the local universities in Guangdong to promote the development of local economy and culture, but can also provide reference to other local universities in 
promoting the development of local economy and culture.

\section{THE INEVITABILITY OF LOCAL UNIVERSITIES SERVING THE DEVELOPMENT OF LOCAL ECONOMY AND CULTURE}

\subsection{The Intrinsic Requirement of Higher Education Function}

The service of local colleges and universities to the development of local economy and culture is the reflection of local colleges and universities following the internal development law of higher education, and is also one of the bases of running colleges and universities. The social service function of colleges and universities was first proposed by the University of Wisconsin in the United States. Its core idea is that the state university should start from the development of the state and serve for the development and construction of the state.

In this way, the social service function of local universities in serving the local economic development began to be widely recognized by the society. Looking back on the development of colleges and universities, we can see that with the development of social economy and culture, colleges and universities have gradually formed the duty of serving the society, that is, training highquality talents for the development of social economy and culture, carrying out scientific and technological innovation and serving for cultural inheritance and innovation. With the advent of the information age and the pursuit of the connotative development of colleges and universities, the function of serving the economic and cultural development of colleges and universities is becoming more and more important.

\subsection{The Need of the Development of Local Economy and Culture}

Local colleges and universities serving the development of local economy and culture is also the need to achieve sustainable and healthy development of regional economy and culture. "Universities can provide advanced technology and a large number of application-oriented talents for regional economic development." [2] By virtue of its own advanced scientific and technological advantages, higher education plays its social service function by training a large number of urgently needed talents for local areas and providing intellectual support for local development. The service function of local colleges and universities is most obvious in the process of local economic and cultural development. Because of its unique geographical and popularity advantages, local colleges and universities have a close relationship with the local government, and offer suggestions for the development of local economic and cultural development, and provide powerful intellectual support.

\section{PROBLEMS IN SERVING LOCAL ECONOMIC AND CULTURAL DEVELOPMENT OF LOCAL COLLEGES AND UNIVERSITIES IN GUANGDONG PROVINCE}

\subsection{Weak Awareness of Active Service to Local Needs}

The consciousness of serving the locality in a local university determines its attitude of serving the locality and influences the effect. However, it is necessary for local colleges and universities to further strengthen their awareness of serving the local people.

The insufficiency of local service consciousness is mainly manifested in the school-running model. In the process of running a school, local colleges and universities should pay attention to exploring the mode of running a school which is suitable for the current situation of local economic and cultural development. However, many ignore the actual situation of local economy and culture and imitate the mode and development concept of key colleges and universities. As universities are located in different regions, in different economic and cultural conditions and with different demand for talents, blind imitation will result in the inconsistency between talent cultivation type and local economic and cultural development needs. Due to the lack of local service awareness, few local colleges and universities in Guangdong set up special departments to serve local economic and cultural development, which can not well enhance teachers' awareness of service to the local. As a result, teachers in local colleges and universities do not consider the needs of local economic and cultural development in their daily teaching, and cannot properly base their teaching on the talent types and professional types required by local economic and cultural development. When graduates enter enterprises, they cannot better meet the actual needs 
of enterprise development, which leads to low employment rate of graduates and slow regional economic development.

\subsection{Inability to Fully Support the Local Economic Development of Talent Demand}

At present, colleges and universities have become an important base for talent training, providing a large number of high-quality talents to the society every year. "The expansion of university enrollment has increased the number of highquality talents and, to some extent, improved the average quality of Chinese citizens, providing more impetus for China's economic and social progress and development." [4] In recent years, the talent market in Guangdong has seen labor shortage in enterprises and difficult employment for students. These problems are caused by a troubled talent training mode of local colleges and universities. The talent training mode is not formulated according to the current situation of local economic and cultural development, with stark in accordance with the requirements of local economic and cultural development. As a result, the talents provided by colleges and universities cannot meet the actual needs of local economic and cultural development.

\subsection{Low Conversion Rate of Scientific Research Achievements}

At the present stage, there are some deviations between the scientific research of local colleges and universities in Guangdong and the needs of regional economic and cultural development, such as the errors in the direction of scientific research and the outdated assessment and evaluation system. Most universities still present their scientific research results in the form of papers, but the practical transformation of scientific research results takes a small proportion in the assessment and evaluation system. As a result, there is a large gap between the scientific research results and the actual needs of economic and cultural development, which is contrary to the purpose of providing support for social development and serving the society.

The deviation between the direction of scientific research and the needs of local economic and cultural development leads to the poor performance of local colleges and universities in serving the society. Due to the big difference between the research direction and the actual situation of local economic and cultural development, the research achievements can only stay at the theoretical level, unable to be translated into practice for local economic and cultural development. In addition, there are not many scientific research groups such as technical alliances jointly established by local universities and local enterprises, with low combination degree of production, teaching and research. Therefore, the high quality scientific and technological achievements produced by local colleges and universities cannot fully meet the needs of enterprises.

\subsection{Inadequate Efforts in Guiding the Local Culture}

Leading the development of local culture is one of the responsibilities of colleges and universities, and it is also an important means to improve their school-running level. At the present stage, universities in Guangdong have made some achievements in leading the development of local culture, "but for the overall situation of cultural development in Guangdong, these achievements still cannot meet all the needs of cultural development" [5]. The development of culture is a long, continuous and slow process. The cultural activities carried out by local colleges and universities as well as the in-depth research and inheritance of local characteristic culture by university teachers are not obvious changes and research results in a short time, which leads to the reluctance of many local colleges and universities to invest too much in culture. Many local colleges and universities only lead the development of local culture at a superficial level, and the study and inheritance of culture are shallow, which haven't achieved good results.

\section{THE PROMOTION PATH OF LOCAL COLLEGES AND UNIVERSITIES SERVING LOCAL ECONOMIC AND CULTURAL DEVELOPMENT IN GUANGDONG}

\subsection{Strengthening Local Positioning and Improving the Sense of Social Service}

Local colleges and universities are closely linked with the development of local economy and culture, and they are an important driving force for the development of local economy and culture. The level and quality of running schools directly affect the development of local economy and culture. In 
order to provide a large number of high-quality talents, complete scientific research achievements and cultural support for the development of economy and culture in Guangdong, local colleges and universities there should strengthen their local positioning and enhance their sense of responsibility and mission by improving their sense of social service. They should actively guide their teachers and students to participate in the regional economic and cultural construction, study the channels of expanding their service to the economic and cultural development. According to the needs of regional economic and cultural development and the characteristics of their university, they should set up special service methods to serve the social and economic development of their university to the greatest extent and promote the economic and cultural development of their region.

\subsection{Grasping the Needs of Local Talents and Cultivating High-quality Applied Talents}

At the present stage, it is difficult for students to get employment and enterprises to recruit in Guangdong area. The reason for this situation is that colleges and universities have not carried out talent training in combination with the needs of economic development in Guangdong after expanding their enrolment scope. As a result, the students cultivated cannot meet the development needs of local enterprises, which further leads to difficulties in employment for students and the slow development of enterprises. At present, Guangdong is in urgent need of compound talents, so local colleges and universities must adjust their talent training mode, so as to avoid much in accordance with the market demand, and failure to provide talents urgently needed for the local economic and cultural development.

As for talent training, the teaching method of integrating production, education and research can be adopted. It "can improve the employment rate of students and the economic development speed of enterprises, thus promoting the economic development of Guangdong" [6]. When carrying out the teaching activities integrating production, learning and research, the school should take the local economic and cultural development needs as the direction, actively cooperate with the local government and enterprises, adjust the talent training mode and teaching curriculum, and provide high quality compound talents for the local economic and cultural development, so as to meet the economic and cultural development needs of Guangdong.

In addition, local colleges and universities should also introduce high-end talents from the society, and organize these talents into research and development teams to carry out research and development in science, technology and culture, so as to better meet and promote the economic and cultural development in Guangdong. Local colleges and universities should also strengthen cooperation with local governments and invite successful local entrepreneurs or experienced experts in economic and cultural fields to take up positions on campus to strengthen the faculty. At the same time, they can also encourage their teachers to take part-time jobs or conduct practical research in local enterprises, so as to better understand the types of talents needed for local economic and cultural development. This will enable universities to better carry out talent training and better promote the development of local economy and culture.

\subsection{Grasping Local Scientific and Technological Needs and Improving the Ability to Transform Scientific and Technological Achievements}

Local colleges and universities are the main force to promote regional economic development and the main base to provide advanced science and technology for it. Through the adjustment of talent training mode, local colleges and universities cultivate inter-disciplinary talents that meet the needs of regional economic development so as to better promote the development of local economy and culture. The technical research and innovation of talents trained by colleges and universities in local enterprises is conducive to the transformation and upgrading of local industrial structure, so as to improve the competitiveness of local industries in the whole country.

Local colleges and universities should combine local enterprises and governments to jointly establish high-tech industrial parks, combine scientific and technological personnel and technology with regional economic development, transform the research and development achievements of colleges and enterprises into production technology, form a new industrial model, and promote the development and progress of regional economy and society. Local colleges and universities can hold seminars on science and technology to encourage teachers to understand the market and enterprises' demand for science and 
technology, and help them determine research topics and directions, so as to realize that their scientific research achievements can provide deeper and comprehensive services for local economic development.

They can invite experts with more experience to work on campus, introduce practical teaching, carry out practical teaching activities according to the needs of local economic development, and organize teachers to hold regular seminars to discuss the market development status and problems existing in enterprise development. In this way, they can adjust the teaching content and courses according to the market and enterprise needs, and determine the career development direction of students as soon as possible.

\subsection{Grasping Local Cultural Needs and Strengthen Cultural Construction and Dissemination}

In general, the cultural research in colleges and universities mainly focuses on the excavation of historical sites, the sorting out of ancient books and the study of folk culture. However, in order to better serve the local economic and cultural development of local colleges and universities, the cultural research of local colleges and universities in Guangdong should not be limited to this. After fully understanding the local historical development and cultural characteristics, the research fields should be determined in combination with the needs of local economic and cultural development.

After determining the research field, colleges and universities should make efforts to develop themselves into the brand endorsement and characteristic presentation of the culture, and take themselves as the carrier to present the local culture to the whole country and even the whole world. Through their own management to strengthen people's understanding of the formation process of local culture and spiritual characteristics, they can promote the development of local culture. Taking Cantonese opera as an example, it is one of the top ten local operas in China, and Guangzhou is the birthplace of Cantonese opera. During its development, Cantonese opera has covered many local cultural characteristics, which is of great research value and worth inheriting. However, against the background of market economy, people do not pay much attention to the inheritance of traditional culture, which makes many people do not know or do not know about Cantonese opera. In order to better inherit Cantonese opera and show its cultural characteristics, colleges and universities in Guangzhou can establish Cantonese opera clubs and hold lectures related to Cantonese opera on campus. This will not only help the spread of Cantonese opera, but also make more people understand and love Cantonese opera, attract a large number of tourists, and thus improve the influence of Cantonese culture. At the same time, local colleges and universities in Guangdong should take the characteristics of Guangdong region as the core when carrying out cultural construction to build unique campus culture. Local colleges and universities should make use of the construction of campus characteristic culture to enhance their own brand awareness, attract more students and tourists to study and travel, so as to serve the society and promote the development of local culture.

\section{CONCLUSION}

To sum up, local colleges and universities are the training bases for talents, science and technology and other demands of local economic and cultural development, as well as an important driving force for the rapid development of local economy and culture. Local colleges and universities should take serving local economic and cultural development as the bedrock of running schools. They should formulate scientific and reasonable training mode in accordance with the needs of local economic and cultural development and school characteristics, improve the consciousness of social service, provide a large number of high-quality talents for local economic and cultural development, and scientific researches that can be used in the practice, and actively guide the teachers and students to be involved in the construction and development of local economy and culture, so as to actively promote the local economic and cultural development.

\section{AUTHORS' CONTRIBUTIONS}

This paper is independently completed by Qiuzhun Wang.

\section{REFERENCES}

[1] Wang Qun. Research on the Construction of Universities Serving Local Economy and Culture from the Perspective of Harmonious Society - Taking Jinan University Serving Jinan as an Example [J]. New West, 2017 (12): 41-43. (in Chinese) 
[2] Yao Fang. Research on Regional Economic Development Served by Local Higher Education [J]. Journal of Liaoning University of Technology (Social Science Edition), 2020, 22(04): 109-111. (in Chinese)

[3] Huang Jie. Research on Local Universities Serving the Economic and Social Development of Local Industries [J]. Police Research \& Exploration (II), 2020(09): 22-23. (in Chinese)

[4] Zou Manli. Research on Local Universities Serving Local Economic and Social Development [D]. North China University of Water Resources and Electric Power, 2019. (in Chinese)

[5] Xue Suming. Analysis of Coupling Elements in the Common Track Development of Regional Higher Education and Local Economy [J]. Heilongjiang Researches on Higher Education, 2017(12): 34-37. (in Chinese)

[6] Zhou Yingbin. The Way of University Library Think Tank Serving Local Economic and Cultural Development - A Case Study of Quanzhou Normal University Library [J]. Journal of Quanzhou Normal University, 2019, 37(04): 82-86. (in Chinese) 